\title{
Sustainable Development and Quality of Life in Poland Compared to other OECD Member Countries
}

\author{
Submitted 11/11/20, 1st revision 15/12/20, 2nd revision 11/01/21, accepted 16/01/21
}

\begin{abstract}
Piotr Misztal ${ }^{1}$
Abstract:

Purpose: The publication aims to analyze the concept of sustainable development in the member countries of the Organization for Economic Cooperation and Development (OECD), emphasizing the quality of life of Polish citizens against the background of other member countries of this organization.

Design/Methodology/Approach: In the study is used a research method based on literature studies in the field of finance and macroeconomics. The first step of the research was to formulate the research problem, then to collect and evaluate relevant data, then to analyze and interpret the collected data, and finally to present the data and present the directions for further research. This article presents a narrative review of the scientific literature and an analysis of statistical data to identify various concepts of sustainable development and quality of life and to identify the main determinants of the quality of life in OECD member countries. Findings: Analyzing selected measures of the sustainable development of OECD member countries in the period 2000-2018, the increase in the inhabitants' social and individual wellbeing and the harmonious arrangement of the relationship between man and the human environment were revealed. The total index of Better Life Index was found that Poland was in this respect in the third tenth of all 37 OECD member countries. Poland achieved better results than the average in the areas of "personal safety," "education," and "balance between work and home life." However, for the remaining eight criteria ("housing," "life satisfaction," "civic engagement," "work and wages," "society," "quality of the environment," "income and wealth," "health"), Poland achieved much worse results than the average for OECD countries.
\end{abstract}

Practical Implications: The progressive degradation of the natural environment was stopped, the effectiveness of using natural resources was increased, and the comfort of the inhabitants' lives was improved in the conditions of progressive economic growth.

Originality/Value: The article is a theoretical analysis of various concepts of sustainable development and quality of life, and an in-depth empirical analysis of the evolution of sustainable development and changes in the quality of life in Poland compared to other OECD member countries. So far, such comprehensive theoretical and empirical research has not been carried out.

Keywords: Sustainable development, quality of life, OECD.

JEL classification: $Q 01, R 13, I 14$.

Research type: Research article.

${ }^{1}$ Prof. Faculty of Law and Social Sciences, The Jan Kochanowski University (JKU) in Kielce,pmisztal@ujk.edu.pl; 


\section{Introduction}

The awareness of the need for sustainable development is growing all over the world. The report of the World Commission on Environment and Development (so-called Brundtland Commission) entitled "Our Common Future" formulated the definition of sustainable development, according to which it is such a development that ensures meeting the needs of the present generation without diminishing the future development opportunities generations (Raport Brundtland, 1991). The approach to sustainable development adopted by the Brundtland Commission was a breakthrough due to the emphasis on the need to integrate activities in social, economic, and environmental development. The key idea of sustainable development is intergenerational equity, which ensures that all generations have equal access to the natural resources, social and economic environment. In each of the areas listed above, appropriate measures should be taken to:

- ensuring access to work, health care, education, sanitation infrastructure, while respecting human rights and maintaining social equality (area of society),

- economic growth conducive to social cohesion and the elimination of poverty, while limiting the negative impact on the natural environment (area of the economy),

- provide the public with ecological security by protecting the natural environment, preserving biodiversity, reducing the consumption of natural resources and their rational use (environment area).

The integrated order system is the ultimate system of sustainable development. The starting point in shaping the integrated order is a system of strategic goals of a social, economic, and environmental nature (Noja and Cristea, 2018). The implementation of these goals is measured using sustainable development indicators.

According to the definition of sustainable development proposed by D. Pearce, A. Markandya, E. Barbiera, "sustainable development involves the creation of a socioeconomic system that will support the following goals: increase in real incomes, raise the level of education, improve the health of the population and - generalizing - the quality of life " (Stanny and Czarnecki, 2011). The goal of sustainable development is achieved through the joint effort of several interrelated parameters and requiring coordination both on the vertical and horizontal levels. There is a dynamic triangular relationship between the three keys, namely environmental, economic and social parameters.

People focused on the social parameter from the triangle's broad base, as active social participation plays an instrumental role. The relationships between population, environment, and development are complex. In addition to the key factors, effective staff capacity building, institutional strengthening, including strong political will, and effective implementation and monitoring mechanism play an equally important role in a successful sustainability outcome. 
Figure 1. Three parameters of sustainable development

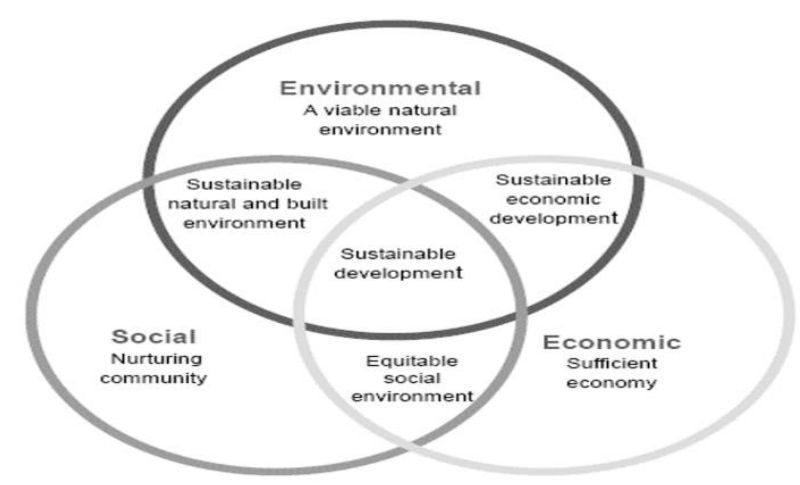

Source: Retrieved from https://saferenvironment.wordpress.com/.

The problem is that although this idea is clearly correct, it is not extremely helpful in determining specific solutions. They rely on individual, practical actions focused on well-defined tasks, which are now set out in the 169 goals of the 17 Sustainable Development Goals (SDGs) adopted at the 2015 UN World Summit. However, it remains obvious that the only way they can operate is to be both concrete and part of the broad concept of sustainable development. Goals and tasks are not isolated but are holistic concepts (Janoušková et al., 2019).

The Sustainable Development Goals centered around the "three E's" - environmental protection, economic growth, and social justice, also correlate with the quality-of-life considerations. Quality of life refers to people's perception of their position in life about their culture, values, and expectations. Improving the quality of life and meeting the present's needs through sustainable development will help ensure that the needs of future generations are more likely to be met (Cusack, 2019).

Czapiński and Panek (2009) pointed out specific factors determining the objective quality of life. It is about such elements as:

- $\quad$ economic activity (functioning on the labor market),

- income situation and income management method,

- food,

- material wealth,

- living conditions, use of social assistance,

- education of children,

- participation in culture and leisure,

- using the services of the health care system,

- insurance and pension security,

- pro-ecological attitudes.

According to a crowd-sourced global database of quality of life information Numbeo, Quality of Life Index is an estimation of overall quality of life by using an empirical formula which takes into account purchasing power index (the higher, the 
better), pollution index (the lower, the better), house price to income ratio (the lower, the better), cost of living index (the lower, the better), safety index (the higher, the better), health care index (the higher, the better), traffic commute time index (the lower, the better) and climate index (the higher, the better).

Based on academic research and several initiatives, " $8+1$ dimension" as an overarching framework for the measurement of well-being. Ideally, they should be considered simultaneously because of potential trade-offs between them:

- Material living conditions (income, consumption, and material conditions),

- Productive or main activity,

- Health Education,

- Leisure and social interactions,

- Economic security and physical safety,

- Governance and basic rights,

- Natural and living environment,

- Overall experience of life.

The quality of life is, therefore, a critical and current issue in the contemporary market economy. It is analyzed in various ways, defined, and measured. One of the characteristics of quality of life is its objective character. An objective approach to quality-of-life concerns, particularly the search for such measures with which quality of life can be identified and measured. These meters should be based on the objective and generally available information (Numbeo, n.a.)

Table 1. Selected indexes of sustainable development and quality of life

\begin{tabular}{|c|c|c|c|c|c|c|c|c|}
\hline & Factors & $\begin{array}{l}\text { Social } \\
\text { Progress } \\
\text { Index } \\
\text { (SPI) }\end{array}$ & $\begin{array}{l}\text { Human } \\
\text { Development } \\
\text { Index (HDI) }\end{array}$ & $\begin{array}{l}\text { Quality } \\
\text { Of Life } \\
\text { (QOL) }\end{array}$ & $\begin{array}{l}\text { Better } \\
\text { Life } \\
\text { Index } \\
\text { (BLI) }\end{array}$ & $\begin{array}{l}\text { Gross } \\
\text { National } \\
\text { Happiness } \\
\text { (GNH) }\end{array}$ & $\begin{array}{l}\text { Happy } \\
\text { Planet } \\
\text { Index } \\
\text { (HPI) }\end{array}$ & $\begin{array}{l}\text { Numbeo } \\
\text { Quality } \\
\text { of Life } \\
\text { Index } \\
\text { (QOL) }\end{array}$ \\
\hline \multirow{11}{*}{ 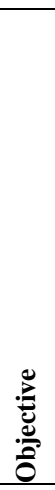 } & Income & $\mathrm{X}$ & $\mathrm{X}$ & $\mathrm{X}$ & $\mathrm{X}$ & $\mathrm{X}$ & & $\mathrm{X}$ \\
\hline & Housing & & & & $X$ & $\mathrm{X}$ & & $\mathrm{X}$ \\
\hline & Jobs & & & $\mathrm{X}$ & $\mathrm{X}$ & & & \\
\hline & Health & $\mathrm{X}$ & $\mathrm{X}$ & $\mathrm{X}$ & $\mathrm{X}$ & $\mathrm{X}$ & $\mathrm{X}$ & $\mathrm{X}$ \\
\hline & Education & $\mathrm{X}$ & $\mathrm{X}$ & & $\mathrm{X}$ & $\mathrm{X}$ & & \\
\hline & Environment & $\mathrm{X}$ & & $\mathrm{X}$ & $\mathrm{X}$ & $X$ & $\mathrm{X}$ & $X$ \\
\hline & Community & & & $\mathrm{X}$ & $\mathrm{X}$ & $X$ & & $\mathrm{X}$ \\
\hline & Safety & $\mathrm{X}$ & & $\mathrm{X}$ & $\mathrm{X}$ & & & $\mathrm{X}$ \\
\hline & $\begin{array}{l}\text { Civil } \\
\text { engagement }\end{array}$ & $\mathrm{X}$ & & $\mathrm{X}$ & $\mathrm{X}$ & & & $\mathrm{X}$ \\
\hline & $\begin{array}{l}\text { Work-Life } \\
\text { balance }\end{array}$ & & & & $\mathrm{X}$ & $\mathrm{X}$ & & \\
\hline & Other & & & & & $\mathrm{X}$ & & \\
\hline 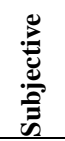 & $\begin{array}{l}\text { Life } \\
\text { Satisfaction }\end{array}$ & & & & $\mathrm{X}$ & $\mathrm{X}$ & $\mathrm{X}$ & \\
\hline
\end{tabular}

Source: Own study. 


\section{Sustainable Development in OECD Member Countries}

The Organization for Economic Co-operation and Development (OECD) is an intergovernmental organization of an economic nature, created on September 30, 1961. The headquarters of this organization in Paris. Today, the OECD comprises 37 member countries, including Poland since 2006, but only 36 member states were included in the study as Colombia became an OECD member in April 2020. This organization's role in the contemporary global economy is significant because, in 2018 , the total share of OECD member countries in the global GDP reached $65 \%$, and the total share of this organization in global trade amounted to $63 \%$.

The basic areas of OECD's activity are to promote sustainable development in the member countries, carry out activities aimed at increasing employment and economic competitiveness, raise the standard of living of citizens, maintain financial stability, and help developing countries (Thalassinos et al., 2019). That is why the OECD undertakes many initiatives that are an inspiration for shaping policies, leading to the improved economic situation and the natural environment, which has the effect of improving the population's quality of life. The economic, intellectual, and scientific potential of the OECD and the possibility of using the knowledge and experience of experts from many institutions and organizations allow the development of comprehensive, complex solutions to overcome contemporary problems and future development challenges (Son et al., 2013; Son and Noja, 2013).

In 2009, the OECD member countries signed the so-called Green Growth Strategy, which main goal is to strengthen policies conducive to economic growth while maintaining environmental goods and developing environment-friendly infrastructure. OECD seeks to identify and limit information gaps in the theory and practice of sustainable development and support member states in defining and implementing green growth policy.

One of the most commonly used sustainable development measures is the Gini coefficient, which shows the relative differences in income between the richest and the poorest. Among OECD member countries in 2018, the largest income inequalities occurred in Chile, Mexico, and the United States. The smallest income diversification was observed in the Nordic countries, such as Iceland, Norway, and Denmark. In Poland, in 2000-2018, a significant reduction in income inequalities and a drop in the Gini coefficient from $37.6 \%$ to $30.0 \%$ were observed. At the same time, significant improvements were found in Portugal, Belgium, and Iceland. The increase in income inequality was observed, among others, in Luxembourg, Slovenia, and Spain.

Also, expenditures on research and development (R\&D) are one of the measures of sustainable development and, at the same time, an indicator of the level of development of the knowledge-based economy. In Poland in 2018, research and development expenditures amounted to $1.2 \%$ of GDP. Despite the increase in research and development expenditure since 1996, this indicator is still lower than the OECD average, which is approaching $2.4 \%$ of GDP. Among the member countries of this 
organization, innovation leaders are South Korea, Israel, and Japan, where R \& D expenditure significantly exceeds $3.5 \%$ of GDP. The lowest intensity of research and development is characterized by Chile, Mexico, and Greece, where the relevant indicators do not exceed $0.9 \%$ of GDP.

One of the important aspects of sustainable development is the issue of the state of the natural environment. It is a gradual departure from traditional energy sources and wider use of renewable energy sources such as water, wind, solar radiation, geothermal processes, and biofuels. Energy-efficient management is also of great importance, as is the increase in the economy's energy efficiency. Energy productivity in Poland in 2018 was higher than the average for OECD countries. At the same time, Poland belongs to the OECD countries, which in 1996-2018 achieved the most significant progress in energy productivity growth. The ratio of GDP to the total primary energy supply improved in Slovakia by $128 \%$, in Poland by $118 \%$, while in the OECD, it increased by almost 38\% (Polska Agencja Inwestycji i Handlu, 2016).

\section{Quality of Life in Poland in Comparison to OECD Countries}

The commonly used socio-economic development measures of countries and regions are based on the System of National Accounts. According to many science representatives, "economists believe that the GDP index is the only and unquestionable measure of welfare" (Kaczyńska, 2001). At the same time, it should be noted that GDP is a measure of production, not wealth, and thus it is most often interpreted by economists (Kubiczek, 2014). The broadly understood prosperity is influenced by many factors of measurable and non-measurable nature, not taken into account when measuring GDP.

An important "disadvantage" of GDP is that this indicator does not show the existing income inequalities between population groups in a given country. GDP in absolute value or per capita is by no means the best measure of the population's standard of living in a given country. GDP per capita, however, measures only average income. It does not reflect the differences between individuals and groups of people. Moreover, they are often tremendous in individual countries.

This indicator does not consider the highly uneven distribution of income existing in most countries of the world, which harms residents' quality of life and is conducive to the increase in crime, decline in labor productivity, and reduction of investments. For if the economic growth concerns mainly the richest people in a given country, even higher taxation of their income will not lead to an increase in the well-being of the majority, poor people, or an increase in investment and employment. Expenses of the richest people for consumption differ from the poorest people's analogous expenses and have a much less favorable impact on economic development (Gwiazda, 2018).

Hence, many economists try to consider the quantitative and the qualitative aspects of living standards when measuring welfare. Formulating an opinion on the level of 
socio-economic development of a country or region based solely on one measure such as GDP growth rate turns out to be too much simplification. This is where the idea of constructing by the OECD a synthetic indicator of the welfare of the country (region) in the form of the Better Life Index (BLI) (OECD, 2018). You can use the index to compare the level of welfare in different regions, based on the 11 criteria that the OECD has identified as important in material living conditions and quality of life. The BLI index considers such criteria as employment, income, the condition of the natural environment, safety, health care, and general satisfaction with life. With these partial indicators, the socio-economic situation is analyzed in 35 industrialized countries belonging to this organization.

The highest prosperity among the analyzed OECD member countries and associated economies is enjoyed by countries such as Norway, Denmark, and Australia. On the other hand, the worst situation is North Africa, Mexico, and Turkey. Compared to other OECD member countries, Poland achieves relatively good results in welfare measured by the index of a better life. Among the OECD member countries, Poland is in this respect at the lower rate of member countries, selling out countries such as Greece, Latvia, and Portugal.

Among all the analyzed indicators of sustainable development, Poland achieved the best position in 2018 in the areas of safety ( 7.8 points out of 10) (9.5 points out of 10 in 2016) and education (7,6 points out of 10) (8.3 points out of 10 in 2016). On the other hand, Poland had the worst position in the areas of income $(2,6$ points out of 10) (1.3 points out of 10 in 2016) and community (4 points out of 10) (5.6 points out of 10 in 2016).

Figure 2. Classification of OECD countries in terms of quality of life

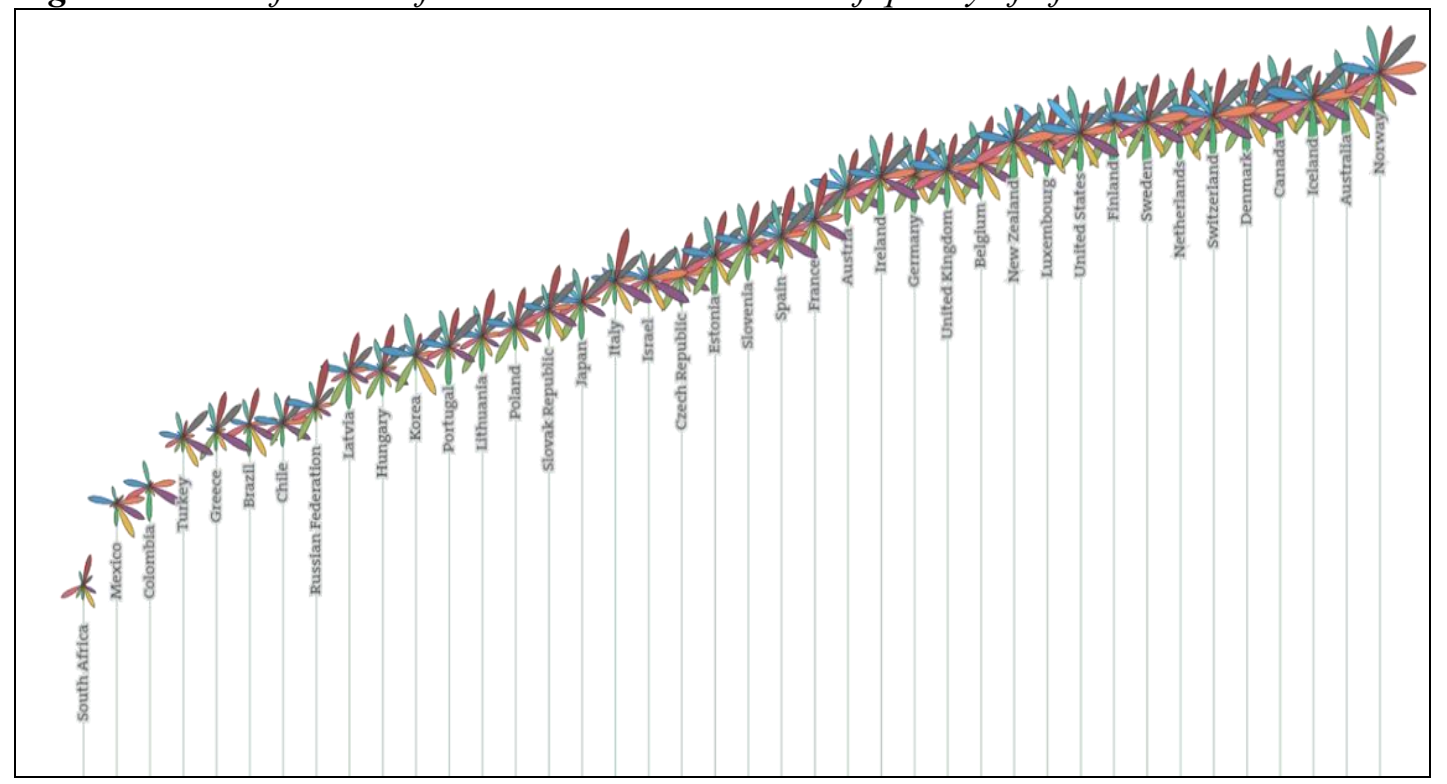

Source: http://www.oecdbetterlifeindex.org. 
It should also be noted that the average quality of life in OECD countries significantly improved in 2018 compared to 2016. The improvement in living conditions is concerned with work-life balance, health, and civic engagement. On the other hand, a significant deterioration in living conditions was recorded in the OECD about income.

Figure 3. Indicators of quality of life in Poland in comparison to OECD countries in 2018

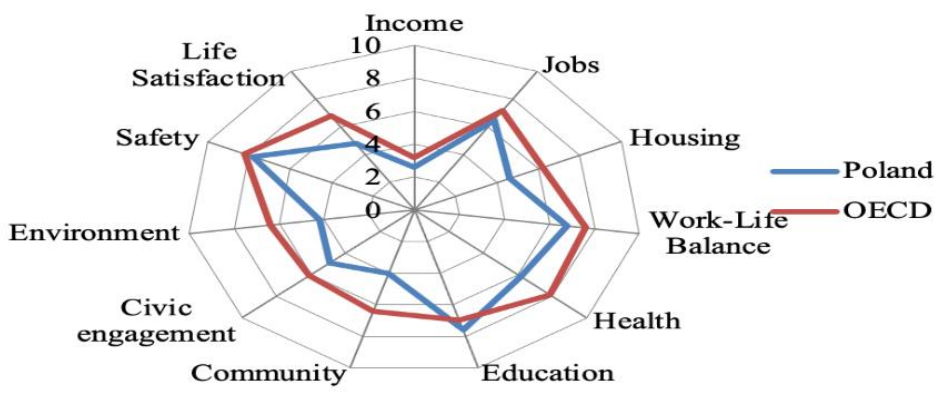

Source: $\underline{\text { http: }: / w w w . o e c d b e t t e r l i f e i n d e x . o r g}$.

Figure 4. Indicators of quality of life in Poland in comparison to OECD countries in 2016

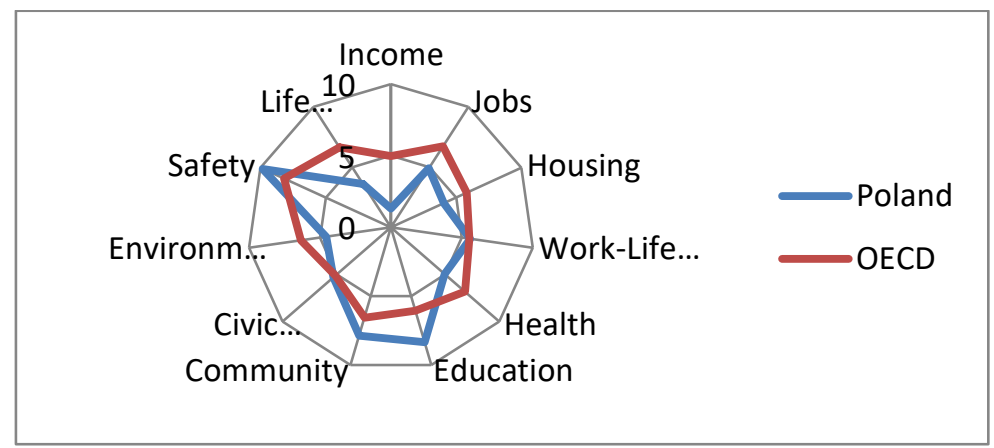

Source: http://www.oecdbetterlifeindex.org.

Although money cannot buy happiness, it is an important means to achieve a high standard of living and a better frame of mind. Higher economic wealth can also improve access to high-quality education, healthcare, and housing. The average annual net disposable income per capita in Poland in 2018 was almost 20.000 USD, while the average annual net disposable income per capita in the OECD was 50\% higher than in Poland and amounted to over 30 thousand. USD. There is a significant gap between the richest and the poorest in Poland, i.e., $20 \%$ of the population earns nearly five times as much as $20 \%$ of the poorest.

Having a job brings many benefits to the residents, including providing income sources, improving social inclusion, fulfilling one's own aspirations, building self- 
esteem, and developing skills and competencies. As far as employment is concerned, in Poland, 66\% of people aged 15-64 had paid work in 2018. For comparison, the average employment rate in the OECD was significantly higher and amounted to $68 \%$. The long-term unemployment rate in Poland was slightly higher than the average unemployment rate in the OECD and was 1.52\% in Poland and the OECD $1.78 \%$. Good education and skills are a critical condition for finding a job. In Poland, as many as $92 \%$ of people aged $25-64$ had at least secondary education in 2018 , while the average OECD rate was $78 \%$.

Most OECD countries enjoy a significant increase in life expectancy over the last decades, thanks to improved living conditions, public intervention in healthcare, and advances in healthcare. Regarding health, it should be noted that Poland's life expectancy was 78 years and was significantly lower than the average life expectancy in the OECD of 80.2 years. In turn, $58 \%$ of the surveyed people enjoyed good health in Poland, while in OECD countries, much more, $69 \%$ of the surveyed people.

People are social beings. The frequency of contact with others and the quality of personal relationships are decisive determinants of welfare. As far as the social sphere is concerned, it should be stated that the feeling of civic community in Poland was lower than the average in OECD countries because $86 \%$ of residents in Poland believed that they knew someone who could rely on in need, but an average score in OECD was $89 \%$. Confidence in the government is essential for social cohesion and welfare. High voter turnout is a measure of citizen participation in the political process. In Poland, a moderate level of civic participation was found, as voter turnout, citizen participation in the political process was 55\% during the last elections. The average voter turnout in OECD countries was significantly higher and amounted to $68 \%$ in this period.

Living in satisfactory housing is one of the most important aspects of people's lives. Regarding housing, there was a relatively worse situation in Poland compared to OECD countries, as the average number of rooms per one inhabitant in Poland was 1.1 , while in the OECD it was 1.8. Completely contrary to the above case, the security situation was presented, and personal security is a basic well-being element. The average number of murders per one hundred thousand inhabitants in Poland was 0.7, while the average for OECD countries was more than five times higher and amounted to 3.7 .

Finding the right balance between work and life is a challenge for all employees, especially working parents. The ability to successfully combine work, family commitments, and personal life are important for all family members' welfare. Governments can help solve this problem by encouraging flexible forms of employment, helping parents achieve a better balance between work and home life. Poland's situation in terms of maintaining a proper balance between work and private life was relatively better than in OECD countries. Namely, the percentage of employees working above 50 hours per week was in Poland almost two times lower than the average in the OECD and amounted to $5.95 \%$. 
The quality of the natural environment has a direct impact on the health and wellbeing of the residents. Air pollution is one of the important environmental problems that directly affect people's quality of life. About the natural environment, the situation in OECD countries was better than in Poland. The average level of atmospheric aerosols (PM2,5) in the region inhabited by Poland's population was 22 $\mu \mathrm{g} / \mathrm{m}^{3}$, while in the OECD countries, the average level was much lower and reached less than $14 \mu \mathrm{g} / \mathrm{m}^{3}$.

Happiness or subjective well-being can be measured in terms of life satisfaction, the presence of positive experiences and feelings, and the lack of negative experiences and feelings. Although subjective, such measures are a useful complement to objective data to compare the quality of life in different countries. Polish residents were slightly less satisfied with their lives than the average population in OECD countries. When asked to assess the overall life satisfaction on a scale of 0 to 10 , Poland's inhabitants rated 6.1, slightly lower than the average for OECD countries of 6.5 .

Table 2. Changes in quality of life in Poland in comparison to OECD countries

\begin{tabular}{|c|c|c|c|c|c|}
\hline \multirow{4}{*}{\begin{tabular}{|l|} 
Obszar \\
Work-Life \\
balance
\end{tabular}} & & \multicolumn{2}{|l|}{2016} & \multicolumn{2}{|l|}{2018} \\
\hline & Indicator & \multicolumn{2}{|l|}{$\begin{array}{ll}2010 \\
\text { Poland }\end{array}$} & Poland & OECD \\
\hline & $\begin{array}{l}\text { Employees working very long } \\
\text { hours (over } 50 \text { hours per } \\
\text { week) }\end{array}$ & $6,68 \%$ & $12,62 \%$ & $5,95 \%$ & $11,01 \%$ \\
\hline & $\begin{array}{l}\text { Time devoted to leisure and } \\
\text { personal care }\end{array}$ & 14,42 & 14,90 & 14,42 & 14,98 \\
\hline \multirow{2}{*}{\begin{tabular}{|l|}
$\begin{array}{l}\text { Civil } \\
\text { engagement }\end{array}$ \\
\end{tabular}} & Voter turnout & $55,0 \%$ & $69,0 \%$ & $55,0 \%$ & $68,0 \%$ \\
\hline & $\begin{array}{l}\text { Stakeholder engagement for } \\
\text { developing regulations }\end{array}$ & 2,6 & 2,4 & 2,6 & 2,4 \\
\hline \multirow[t]{3}{*}{ Education } & Educational attainment & $91,0 \%$ & $74,0 \%$ & $92 \%$ & $78 \%$ \\
\hline & Student skills & 504 & 486 & 504 & 486 \\
\hline & Years in education & 17,7 & 17,0 & 17,6 & 17,2 \\
\hline \multirow[t]{4}{*}{ Jobs } & Employment rate & $65,0 \%$ & $67,0 \%$ & $66,0 \%$ & $68,0 \%$ \\
\hline & $\begin{array}{ll}\text { Long-term unemployment } \\
\text { rate }\end{array}$ & $2,14 \%$ & $2,04 \%$ & $1,52 \%$ & $1,78 \%$ \\
\hline & $\begin{array}{l}\text { Uncertainty in the labor } \\
\text { market }\end{array}$ & $4,3 \%$ & $4,9 \%$ & $5,7 \%$ & $7,0 \%$ \\
\hline & Personal earnings & 25921 USD & \begin{tabular}{|l}
44290 \\
USD
\end{tabular} & $\begin{array}{ll}27 & 046 \\
\text { USD }\end{array}$ & $\begin{array}{ll}43 & 241 \\
\text { USD }\end{array}$ \\
\hline Community & Quality of support network & $89,0 \%$ & $89,0 \%$ & $86 \%$ & $89,0 \%$ \\
\hline \multirow[t]{2}{*}{ Environment } & Air pollution (PM2,5) & $22,0 \mu \mathrm{g} / \mathrm{m}^{3}$ & $14,0 \mu \mathrm{g} / \mathrm{m}^{3}$ & $\begin{array}{l}22,0 \\
\mu \mathrm{g} / \mathrm{m}^{3}\end{array}$ & $\begin{array}{l}14,0 \\
\mu \mathrm{g} / \mathrm{m}^{3}\end{array}$ \\
\hline & Water quality & $80,0 \%$ & $81 \%$ & $82 \%$ & $81 \%$ \\
\hline \multirow[t]{2}{*}{ Income } & $\begin{array}{l}\text { Household net adjusted } \\
\text { disposable income }\end{array}$ & 18906 USD & $\begin{array}{l}30563 \\
\text { USD } \\
\end{array}$ & \begin{tabular}{|l}
19814 \\
USD
\end{tabular} & \begin{tabular}{|l|}
33604 \\
USD \\
\end{tabular} \\
\hline & $\begin{array}{|lll|}\begin{array}{l}\text { Household } \\
\text { wealth }\end{array} & \text { net financial } \\
\end{array}$ & 14997 USD & $\begin{array}{l}90570 \\
\text { USD }\end{array}$ & $\begin{array}{l}210991 \\
\text { USD }\end{array}$ & $\begin{array}{l}408 \quad 376 \\
\text { USD }\end{array}$ \\
\hline
\end{tabular}




\begin{tabular}{|l|l|l|l|l|l|}
\hline \multirow{2}{*}{ Health } & Life expectancy & 77,6 & 80,1 & 78,0 & 80,2 \\
\cline { 2 - 6 } & Self-reported health & $58 \%$ & $69 \%$ & $58 \%$ & $69 \%$ \\
\hline \multirow{3}{*}{ Safety } & Homicide rate & 0,8 & 3,6 & 0,7 & 3,7 \\
\cline { 2 - 6 } & $\begin{array}{l}\text { Feeling safe walking alone at } \\
\text { night }\end{array}$ & $66,3 \%$ & $68,6 \%$ & $67,3 \%$ & $68,4 \%$ \\
\cline { 2 - 6 } & $\begin{array}{l}\text { Rooms per person } \\
\text { facilities without basic }\end{array}$ & $2,7 \%$ & $2,1 \%$ & $3,0 \%$ & $4,4 \%$ \\
\cline { 2 - 6 } & Housing expenditure & $23,0 \%$ & $20,0 \%$ & $22,0 \%$ & $20,0 \%$ \\
\hline $\begin{array}{l}\text { Life } \\
\text { Satisfaction }\end{array}$ & Life satisfaction & 6,0 & 6,5 & 6,1 & 6,5 \\
\hline
\end{tabular}

The lack of change in comparison to 2016

Positive change in comparison to 2016

Negative change in comparison to 2016

Source: http://www.oecdbetterlifeindex.org

Considering the partial indices that make up the Total Better Life Index, it can be concluded that Poland, compared to OECD countries, is above the average level of personal security, education, skills, and work-life balance, but below the average of health, income and assets, social connections, civic engagement, subjective wellbeing, jobs and earnings, and the quality of the natural environment. Moreover, it can be noticed that about the results from 2016, Poland recorded a greater improvement in most of the partial indices constituting the sum of the better life index than the average in OECD member countries. These changes resulted in a relative improvement in the value of the better life index in Poland about OECD countries. Thus, in the analyzed period, Poland gradually narrowed the gap in quality of life to OECD countries.

\section{Conclusions}

Sustainability centers around intergenerational equality-based essentially on threedimensional distinct but interconnected pillars, namely the environment, economy, and society. Policymakers must constantly bear in mind the relationship, complementarity, and trade-offs between these pillars and ensure responsible human behavior and action at international, national, community, and individual levels to uphold and promote this paradigm's assumptions in the interests of human development. In particular governments, the private sector, and civil society organizations need to do more in terms of the policy, education, and regulation of social, economic, and environmental resources to ensure developmentally aware, informed, cultural, and compliant sustainable development for all. The consequence of these actions will ultimately improve the inhabitants' quality of life (Mensah, 2019).

Extremely resistant to the global economic and financial crisis of 2009, Poland is still developing dynamically, catching up with other OECD countries in terms of GDP per capita. Productivity grows relatively quickly, but this process must be continued to maintain convergence with other OECD economies because the level of productivity 
is still relatively low, as is the share of technology in Polish exports. Also, Poland is facing severe demographic pressure due to the low rate of birth rate and the negative net migration balance. Demographic problems may cause problems in the future to maintain dynamic economic growth, limiting Poland's ability to finance adequate pension expenditures and health care.

At present, Poland achieves such a high level of prosperity and quality of life in the OECD that it has not recorded in its history so far. Poland achieves better results than the average OECD country regarding personal safety, education, skills, and the balance between work and private life. However, jobs, housing, and health outcomes are less favorable than in other OECD member countries. Poland's main environmental problem is the low air quality reflected by the high level of air pollution in cities. This is related, among others, to the strong dependence of the Polish economy on the low quality of hard coal and the country's heavy dependence on road transport.

Nowadays, many indicators are measuring sustainable development and quality of life. Their indexes are prepared by various international organizations or state statistical offices. Analytical tools used by analysts are systematically developed and inference methods that enable building comprehensive forecasts and analyses. Presently, statisticians agree that it is impossible to assess sustainable development and the quality of life with one or two parameters. When constructing indices, many aspects must be considered that affect citizens' standard of living and well-being. However, it is worth remembering that it is impossible to build a universal, multidimensional happiness indicator for international comparisons. This results from the selection of data and social, cultural, economic, political, or historical aspects. Therefore, although international indexes allow a comparative assessment of the level of socio-economic development of various regions of the world, they do not give a definite answer to the question of why the inhabitants of a given country are happy than the inhabitants of other countries. ${ }^{2}$

\section{References:}

Cusack, C. 2019. Sustainable Development and Quality of Life. In: Sinha B. (eds), Multidimensional Approach to Quality-of-Life Issues. Springer, Singapore. https://doi.org/10.1007/978-981-13-6958-2_3.

Czapiński, J., Panek, T. 2009. Social Diagnosis 2009. The Council for Social Monitoring. University of Finance and Management in Warsaw.

Gwiazda, A. 2018. GDP - negative economic success rate. Obserwator finansowy. Retrieved from: https://www.obserwatorfinansowy.pl.

Janoušková, S., Hák, T., Ne`cas, V., Moldan, B. 2019. Sustainable Development - A Poorly Communicated Concept by Mass Media. Another Challenge for SDGs? Sustainability, 11.

Kaczyńska, B. 2001. Pomiar i monitoring w polityce społecznej. Polityka Społeczna, 5-6.

\footnotetext{
${ }^{2}$ Wskaźniki jakości życia - PKB, HDI, HPI i inne. Jakie wnioski możemy na ich podstawie wyciagnąć? https://ideologia.pl/wskazniki-jakosci-zycia.
} 
Kubiczek, A. 2014. Jak mierzyć dziś rozwój społeczno-gospodarczy krajów? Nierówności Społeczne a Wzrost Gospodarczy, 8(2).

Mensah, J. 2019. Sustainable development: Meaning, history, principles, pillars, and implications for human action: Literature review. Cogent Social Sciences, 5(1).

Noja, G.G., Cristea, M. 2018. Working Conditions and Flexicurity Measures as Key Drivers of Economic Growth: Empirical Evidence for Europe 1. Ekonomicky Casopis, 66(7), 719-749.

Numbeo. Quality of life. Retrieved from: https://www.numbeo.com/quality-of-life.

OECD Better Life Index. Retrieved from: http://www.oecdbetterlifeindex.org.

Polska Agencja Inwestycji i Handlu. 2016. Retrieved from: http://www.paih.gov.pl.

Raport Brundtland. 1991. Nasza wspólna przyszłość. Raport Światowej Komisji do Spraw Środowiska i Rozwoju pod kierunkiem G.H. Brundtland. PWE, Warszawa.

Safe Environment. Retrieved from: https://saferenvironment.wordpress.com.

Son, L., Noja, G.G., Ritivoiu, M., Tolteanu, R. 2013. Education and economic growth: An empirical analysis of interdependencies and impacts based on panel data. Timisoara Journal of Economics and Business 6(19), 39-54.

Son, L., Noja, G.G. 2013. The role of the human capital and investment in human capital within the sustainable socio-economic development. How labour force migration affects competitiveness? Theoretical and Applied Economics, 18(10(587)), 111126.

Stanny, M., Czarnecki, A. 2011. Zrównoważony rozwój obszarów wiejskich zielonych płuc polski. Próba analizy empirycznej. Instytut Rozwoju Wsi i Rolnictwa Polskiej. Akademii Nauk, Warszawa.

Stat.gov.pl. 2016. Polska w OECD 1996-2016. GUS, Warszawa.

Thalassinos, E., Cristea, M., Noja, G.G. 2019. Measuring active ageing within the European Union: implications on economic development. Equilibrium. Quarterly Journal of Economics and Economic Policy, 14(4), 591-609. https://doi.org/10.24136/eq.2019.028. 